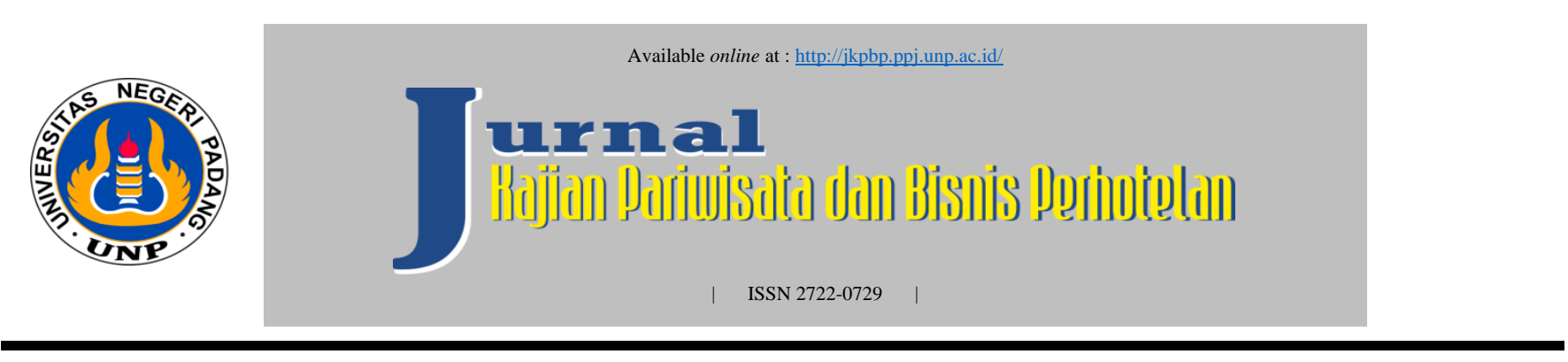

\title{
Strategi Positioning Hotel Rangkayo Basa Kota Padang
}

\author{
Putik Kenanga $^{1}$, Arif Adrian ${ }^{2}$ \\ ${ }^{1}$ Universitas Negeri Padang \\ ${ }^{2}$ Universitas Negeri Padang \\ email :putikkenanga0112@gmail.com, arif.adrian@fpp.unp.ac.id
}

\begin{abstract}
ABSTRAK
Penelitian ini di latar belakangi oleh beberapa masalah yang timbul mengenai positioning Hotel Rangkayo Basa, diantaranya yaitu positioning yang ditinjau dari indikator berdasarkan atribut, positioning berdasarkan produk, positioning harga, positioning berdasarkan pesaing. Penelitian bertujuan untuk mengetahui Strategi Positioning dengan menggunakan analisis SWOT yang dapat ditinjau dengan 4 indikator berdasarkan atribut, positioning berdasarkan produk, positioning harga, positioning berdasarkan pesaing. Penelitian ini merupakan penelitian deskriptif dengan data kualitatif. Teknik pengumpulan data dilakukan dengan metode observasi, wawancara, dan dokumentasi yang melibatkan informan dengan menggunakan teknik purposive sampling. Analisis data secara reduksi yaitu merangkum, memfokuskan ke hal-hal yang penting, serta menganalisis data yang diperoleh terhadap masalah yang di teliti.
\end{abstract}

Kata kunci : Strategi, Positioning, Hotel Rangkayo Basa Kot Padang 


\section{PENDAHULUAN}

Menurut [1] tentang Kepariwisataan, pariwisata adalah bagian dari pariwisata yang didukung oleh berbagai fasilitas dan layanan yang disediakan oleh masyarakat, pengusaha, pemerindah dan pemerintah daerah. Salah satu sektor pariwisata yang berkembang pesat saat ini adalah industri perhotelan. Menurut [2], "Hotel adalah perusahaan akomodasi yang menyediakan fasilitas akomodasi untuk umum dan dilengkapi dengan satu atau lebih jasa catering, layanan kamar, layanan seragam, pencucian linen, penggunaan furniture serta memenuhi persyaratan ketentuan pemerintah". Persaingan yang semakin ketat di hotel-hotel di patong menjadi tantangan bagi strategi positioning.

Menurut [3] menjelaskan bahwa "Positioning ialah merancang perilaku produk dan citra perusahaan untuk menempati posisi khusus dalam pemikiran pasar sasaran”. Menurut [4] memaparkan dalam memutuskan positioning yang efesien, perusahaan dapat menggunakan beberapa dasar positioning yaitu positioning berdasarkan atribut, positioning menurut produk, positioning menurut harga dan positioning menurut pesaing.

Hotel Rangkayo Basa Padang merupakan salah satu hotel berbintang dua di Kota Padang yang terletak di Jln. Hang Tuah No.211, Belakang Tangsi, Kecamatan Padang Barat, Kota Padang. Hotel ini memiliki prinsip syariah. Menurut [5] "Hotel syariah merupakan suatu jasa akomodasi yang beroperasi dan menganut prinsip-prinsip pedoman ajaran Islam".

Tabel 2.Occupancy Hotel Rangkayo Basa

\begin{tabular}{|c|c|c|}
\hline No & Tahun & Occupancy \\
\hline 1 & 2017 & 7.941 \\
\hline 2 & 2018 & 11.726 \\
\hline 3 & 2019 & 9.587 \\
\hline 4 & 2020 & 2.780 \\
\hline
\end{tabular}

Sumber: Front office department Hotel Rangkayo Basa

Dilihat pada tabel diatas bahwasanya tingkatan hunian kamar sepanjang 4 tahun terakhir tidak normal. Persaingan hotel yang terus menjadi kompetitif di Padang ialah tantangan untuk Hotel Rangkayo Basa buat memastikan strategi positioning. Dengan visi serta misi dalam menggapai tujuan gimana mengemas suatu produk bermutu, menarik serta disenangi oleh tamu. Industri butuh menetapkan strategi positioning yang pas buat memperoleh pangsa pasar.

Bersumber pada pada pengamatan yang penulis jalani sepanjang melakukan praktek lapangan industri( PLI) pada bulan Agustus sampai Desember 2020 di Hotel Rangkayo Basa Kota Padang, nampak sebagian kasus yang ditemui terpaut dengan positioning Hotel Rangkayo Basa dimana positioning bersumber pada atribut yang meliputi lambang hotel ialah minimnya simbol- simbol yang melambangkan hotel rangkayo basa selaku hotel syariah sehingga tamu tidak mengenali Rangkayo Basa ialah hotel syariah, setelah itu kasus selanjutnya menimpa positioning bersumber pada produk ialah sarana serta service yang diberikan tidak memuaskan, setelah itu permasalahan berikutnya menimpa positioning bersumber pada pesaing yang meliputi desain bidang dalamnya hotel Rangkayo Basa kurang menarik serta kurang melambangkan syariah. Hingga dari itu occupancy kamar mengalami penyusutan maka dirasa penting untuk mengetahui strategi yang tepat dengan analisis SWOT. Menurut[6] analisis SWOT merupakan identifikasi sebagian aspek secara sistematis buat bisa mengoptimalkan kekuatan (Strength), kelemahan (Weakness), kesempatan (Oppoturnities), ancaman (Threats). Analisis SWOT digunakan untuk mengetahui permasalahan tentang strategi positioning hotel Rangkayo Basa Kota Padang. 


\section{METODOLOGI}

Penelitian ini menggunakan jenis penelitian deskriptif dengan pendekatan kualitatif. Menurut [7] "menyatakan bahwa metode deskriptif adalah metode dengan penelitian yang tidak membuat perbandingan variabel pada sampel yang lain atau mencari hubungan variabel dengan variabel lain". Penentuan informan yang dilakukan yaitu secara purposive sampling. Alat yang digunakan untuk mengumpulkan data dalam penelitian ini adalah peneliti sendiri dengan menggunakan alat bantuan panduan observasi dan wawancara. Wawancara ini dilakukan dengan seperangkat pertanyaan yang disusun sistematis untuk memperoleh informasi secara lengkap. Instrumen yang digunakan yaitu membuat pedoman wawancara berupa pertanyaan yang akan diajukan kepada General Manager, Sales Marketing, Biro Travel Agent, Tamu Hotel Rangkayo Basa. Teknis analisis data dengan cara mereduksi data, lalu menyajikan data dalam bentuk uraian singkat, kemudian menyimpulkan data yang telah disajikan.

\section{HASIL DAN PEMBAHASAN}

1. Formulasi Strategi Positioning Hotel Rangkayo Basa Kota Padang a. Formulasi strategi berdasarkan atribut

Tabel 8. Matriks SWOT Atribut

\begin{tabular}{|c|c|c|}
\hline IFAS & $\begin{array}{l}\text { STRENGTHS (S) } \\
\text { 1. Terdapat ciri khas } \\
\text { pada huruf RB seperti } \\
\text { tulisan kaligrafi. } \\
\text { 2. Berada pada lokasi } \\
\text { yang strategis. }\end{array}$ & $\begin{array}{l}\text { WEAKNESSES }(\mathbf{W}) \\
\text { 1. Lambang kurang } \\
\text { menonjolkan } \\
\text { syariah. } \\
\text { 2. Lambang tidak } \\
\text { dapat terlihat jelas } \\
\text { apabila dicetak } \\
\text { pada banner. } \\
\text { 3. Keberadaan/lokasi } \\
\text { hotel berada pada } \\
\text { zona merah } \\
\text { tsunami. }\end{array}$ \\
\hline $\begin{array}{l}\text { OPPORTUNITES (O) } \\
\text { 1. Kesempatan untuk } \\
\text { mengenali, } \\
\text { menampilkan ciri } \\
\text { khas lambang hotel. } \\
\text { 2. Memberikan } \\
\text { gambaran dan kesan } \\
\text { dibenak tamu. } \\
\text { 3. Keberadaan lokasi } \\
\text { yang strategis dapat } \\
\text { meningkatkan } \\
\text { occupancy hotel. }\end{array}$ & $\begin{array}{l}\text { STRATEGI (SO) } \\
\text { 1. Dengan } \\
\text { mengkombinasikan } \\
\text { warna yang lebih } \\
\text { mencolok pada } \\
\text { tulisan huruf RB } \\
\text { agar lebih mudah } \\
\text { untuk dikenali tamu. }\end{array}$ & $\begin{array}{lr}\text { STRATEGI (WO) } \\
\text { 1. } & \text { Menambahkan } \\
\text { lambang } & \text { khutbah } \\
\text { masjid } & \text { yang } \\
\text { bercorak } & \text { batik } \\
\text { simpel dan } & \text { elegan } \\
\text { agar } & \\
\text { menggambarkan } \\
\text { bahwa r hotel } \\
\text { Rangkayo } & \text { Basa } \\
\text { merupakan } & \text { hotel } \\
\text { syariah } & \text { yang } \\
\text { berlokasi diranah } \\
\text { minangkabau Kota } \\
\text { Padang. } \\
\text { 2. } & \text { Dengan menganti } \\
\text { warna } & \text { lambang } \\
\text { menjadi } & \text { hijau dan } \\
\end{array}$ \\
\hline
\end{tabular}




\begin{tabular}{|c|c|c|}
\hline & & 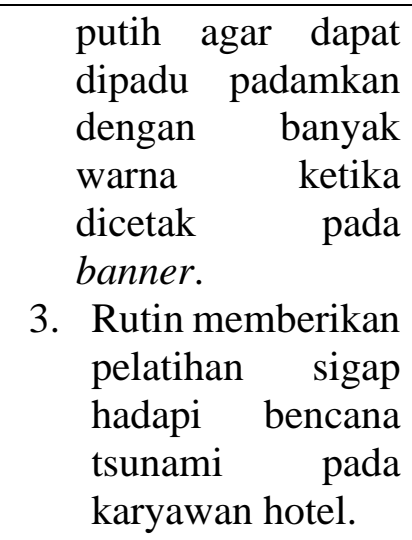 \\
\hline $\begin{array}{l}\text { THREATS (T) } \\
\text { 1. Ancaman pada } \\
\text { lambang akan } \\
\text { bersaing dengan } \\
\text { hotel lain yang lebih } \\
\text { memiliki ciri khas. } \\
\text { 2. Tamu masih ragu } \\
\text { akan hotel rangkayo } \\
\text { basa merupakan } \\
\text { hotel konvensional } \\
\text { atau syariah. } \\
\text { 3. Minimnya waktu } \\
\text { untuk } \\
\text { menyelamatkan diri } \\
\text { pada saat bencana } \\
\text { tsunami terjadi. }\end{array}$ & $\begin{array}{l}\text { STRATEGI (ST) } \\
\text { 1. Dengan } \\
\text { menambahkan } \\
\text { ukiran pada huruf } \\
\text { agar pesaing tidak } \\
\text { dapat menirunya. }\end{array}$ & $\begin{array}{l}\text { STRATEGI (WT) } \\
\text { 1. Untuk menimalisir } \\
\text { kesalah pahaman } \\
\text { tamu terhadap } \\
\text { status hotel } \\
\text { sehingga } \\
\text { memberikan } \\
\text { tambahan pada } \\
\text { nama lambang } \\
\text { rangkayo basa } \\
\text { muslim friendly. } \\
\text { 2. Memberikan } \\
\text { pelatihan kepada } \\
\text { karyawan sebagai } \\
\text { pemandu, } \\
\text { membuat } \\
\text { keterangan agar } \\
\text { bisa dipahami } \\
\text { dan dipelajari } \\
\text { dalam mengatasi } \\
\text { kepanikan bencana } \\
\text { agar tamu tidak } \\
\text { merasa khawatir. }\end{array}$ \\
\hline
\end{tabular}

Sumber: Data olahan

b. Formulasi strategi berdasarkan produk

Tabel 9. Matriks SWOT Produk

\begin{tabular}{|l|l|l|}
\hline IFAS & $\begin{array}{l}\text { STRENGTHS (S) } \\
\text { 1. } \begin{array}{l}\text { Bersetifikat halal } \\
\text { MUI. }\end{array}\end{array}$ & $\begin{array}{l}\text { WEAKNESSES (W) } \\
\text { 1. Memiliki jaringan wifi } \\
\text { 2. }\end{array}$ \\
& $\begin{array}{l}\text { Kebersihan kamar. } \\
\text { di Rangkayo Basa } \\
\text { sudah sangat baik. }\end{array}$ & $\begin{array}{l}\text { 2. Tidak memiliki menu } \\
\text { yang ciri khas. }\end{array}$ \\
& $\begin{array}{l}\text { 3. Ac yang kurang dingin. } \\
\text { 3emiliki mushola } \\
\text { yang besar dan } \\
\text { unik karena ada }\end{array}$ & 4. Area parkir sempit. \\
&
\end{tabular}




\begin{tabular}{|c|c|c|}
\hline EFAS & $\begin{array}{ll}\text { beduk } & \text { besar } \\
\text { disamping } & \\
\text { mushola. } & \end{array}$ & \\
\hline $\begin{array}{l}\text { OPPORTUNITIES (O) } \\
\text { 1. Dapat memberikan } \\
\text { kesan yang baik } \\
\text { kepada tamu. } \\
\text { 2. Mendapatkan } \\
\text { kepercayaan } \\
\text { terhadap produk } \\
\text { yang dijual. } \\
\text { 3. Konsep syariah } \\
\text { memberikan rasa } \\
\text { aman karena terjaga } \\
\text { kehalalannya. } \\
\text { 4. Jika dikontrol, jika } \\
\text { ada perbaikan akan } \\
\text { mempengaruhi tamu } \\
\text { untuk berkunjung } \\
\text { kembali. } \\
\text { 5. Meningkatkan } \\
\text { kenyamanan tamu } \\
\text { saat beribadah. }\end{array}$ & $\begin{array}{l}\text { STRATEGI (SO) } \\
\text { 1. } \text { Meningkatkan } \\
\text { kualitas produk } \\
\text { untuk } \\
\text { memberikan } \\
\text { kepuasan tamu } \\
\text { sehingga dapat } \\
\text { menimbulkan } \\
\text { loyalitas bagi } \\
\text { tamu } \\
\text { berpotensi } \\
\text { terjadinya } \\
\text { booking. }\end{array}$ & $\begin{array}{l}\text { STRATEGI (WO) } \\
\text { 1. Menjadwalkan cooling } \\
\text { system pada wifi disaat } \\
\text { jam-jam tidur (3-4pagi) } \\
\text { sehingga tamu tidak } \\
\text { terganggu dengan } \\
\text { kejadian tersebut. } \\
\text { 2. Pihak hotel } \\
\text { menambahkan } \\
\text { beberapa menu khas } \\
\text { arab pada setiap hari } \\
\text { jumat yang merupakan } \\
\text { hari yang sangat mulia } \\
\text { dalam agama islam. }\end{array}$ \\
\hline $\begin{array}{l}\text { THREATS (T) } \\
\text { 1. Akan ada kompetitor } \\
\text { yang menawarkan } \\
\text { produk yang lebih } \\
\text { baik dan menarik. } \\
\text { 2. Akan hilangnya } \\
\text { kesan tamu terhadap } \\
\text { produk hotel. }\end{array}$ & $\begin{array}{l}\text { STRATEGI ST } \\
\text { 1. Mempertankan } \\
\text { dan } \\
\text { meningkatkan } \\
\text { kualitas produk } \\
\text { akan membuat } \\
\text { tamu nyaman dan } \\
\text { loyal terhadap } \\
\text { hotel. } \\
\text { 2. Memberikan } \\
\text { pelatihan dan } \\
\text { reward kepada } \\
\text { karyawan tentang } \\
\text { prosedur } \\
\text { roomattendant } \\
\text { yang baik dan } \\
\text { benar. }\end{array}$ & $\begin{array}{l}\text { STRATEGI WT. } \\
\text { 1. Selalu mengadakan } \\
\text { pengecekan berkala } \\
\text { pada router wifi agar } \\
\text { jaringan dapat stabil } \\
\text { setiap saat. } \\
\text { 2. meminimalisir keadaan } \\
\text { dengan membeli lahan } \\
\text { kosong yang ada } \\
\text { disamping hotel guna } \\
\text { ketika kamar dalam } \\
\text { keadaan full } \\
\text { accoupancy akan } \\
\text { memudahkan tamu } \\
\text { dalam mencari tempat } \\
\text { parkir. } \\
\text { Melakukan } \\
\text { maintenance Ac secara } \\
\text { berkala agar guna } \\
\text { mengantisipasi } \\
\text { kerusakan barang } \\
\text { secara tiba-tiba. }\end{array}$ \\
\hline
\end{tabular}


Tabel 10. Matriks SWOT Harga

\begin{tabular}{|c|c|c|}
\hline EFAS & $\begin{array}{l}\text { STRENGHT (S) } \\
\text { 1. Adanya promo atau } \\
\text { potongan harga } \\
\text { untuk tamu } \\
\text { langganan. } \\
\text { 2. Paket meeting room } \\
\text { sangat bersahabat. } \\
\text { 3. Harga kamar murah. }\end{array}$ & $\begin{array}{l}\text { WEAKNESS (W) } \\
\text { 1. Pemberian diskon } \\
\text { akan mengurangi } \\
\text { income hotel. }\end{array}$ \\
\hline $\begin{array}{l}\text { OPPORTUNITES (O) } \\
\text { 1. Pemberian diskon dapat } \\
\text { menarik perhatian tamu. } \\
\text { 2. Peluang bagi tamu bisnis. } \\
\text { 3. Memberikan kesan kepada } \\
\text { tamu. }\end{array}$ & $\begin{array}{l}\text { STRATEGI SO } \\
\text { 1. Untuk menarik } \\
\text { perhatian tamu hotel } \\
\text { dapat memberikan } \\
\text { diskon khusus pada } \\
\text { hari besar Islam. } \\
\text { 2. Pihak hotel harus } \\
\text { giat melakukan } \\
\text { promosi paket } \\
\text { meetingdan kamar } \\
\text { dengan menonjolkan } \\
\text { yang akan } \\
\text { dipasarkan. }\end{array}$ & $\begin{array}{l}\text { STRATEGI WO } \\
\text { 1. Membuat program } \\
\text { membership untuk } \\
\text { menarik tamu-tamu } \\
\text { bisnis. }\end{array}$ \\
\hline $\begin{array}{l}\text { THREATS (T) } \\
\text { 1. Akan bersaing dengan hotel } \\
\text { lain yang lebih menawarkan } \\
\text { harga yang lebih murah dan } \\
\text { fasilitas yang lebih baik dari } \\
\text { hotel rangkayo basa. } \\
\text { 2. Pesaing ikut serta membuat } \\
\text { program membership. }\end{array}$ & $\begin{array}{l}\text { STRATEGI ST } \\
\text { 1. Selalu memberikan } \\
\text { informasi mengenai } \\
\text { promo yang akan } \\
\text { ditawarkan kepada } \\
\text { tamu. } \\
\text { 2. Menciptakan suatu } \\
\text { keunikan pada } \\
\text { promo agar pesaing } \\
\text { tidak dapat } \\
\text { menirunya. }\end{array}$ & $\begin{array}{l}\text { STRATEGI WT } \\
\text { 1. Para marketing } \\
\text { harus giat dalam } \\
\text { menciptakan promo } \\
\text { yang menarik agar } \\
\text { anggota merasa } \\
\text { puas. } \\
\text { 2. Dengan promo yang } \\
\text { menarik maka tamu } \\
\text { bisnis dapat } \\
\text { bertahan lama dan } \\
\text { tidak melirik kepada } \\
\text { pesaing lainnya. }\end{array}$ \\
\hline
\end{tabular}

Sumber: Data olahan 
Tabel 11. Matriks SWOT Pesaing

\begin{tabular}{|c|c|c|}
\hline EFAS & $\begin{array}{l}\text { STRENGTHS (S) } \\
\text { 1. Standar operasioanal } \\
\text { prosedure check-in } \\
\text { sesuai syariat islam. } \\
\text { 2. karyawan yang } \\
\text { ramah. } \\
\text { 3. Memiliki desain } \\
\text { interior mushola yang } \\
\text { unik. } \\
\text { 4. Perpaduan warna } \\
\text { lampu tidak merusak } \\
\text { pandangan mata. }\end{array}$ & $\begin{array}{l}\text { WEAKNESSES (W) } \\
\text { 1. Proses check-in dan } \\
\text { check-out lama. } \\
\text { 2. Karyawan kurang } \\
\text { tanggung jawab dan } \\
\text { emphaty dalam } \\
\text { memberikan } \\
\text { pelayanan. } \\
\text { 3. Kurang siggap dalam } \\
\text { menghadapi komplain } \\
\text { tamu. } \\
\text { 4. Desain interior hotel } \\
\text { kurang menonjolkan } \\
\text { syariah. } \\
\text { 5. Desain pada warna } \\
\text { interior } \\
\text { mencolok. kurang }\end{array}$ \\
\hline $\begin{array}{l}\text { OPPORTUNITIES (O) } \\
\text { 1. Mendapatkan kesan } \\
\text { yang baik dari tamu. } \\
\text { 2. Memberikan } \\
\text { kenyamanan bagi } \\
\text { tamu yang menginap. } \\
\text { 3. Akan menjadi } \\
\text { peluang apabila } \\
\text { memiliki desain unik } \\
\text { dan instagrammble. }\end{array}$ & $\begin{array}{l}\text { STRATEGI SO } \\
\text { 1. Menjaga dan } \\
\text { meningkatkan standar } \\
\text { operasional prosedur } \\
\text { service excellence } \\
\text { dengan baik akan } \\
\text { membuat tamu } \\
\text { merasa nyaman dan } \\
\text { loyal kepada } \\
\text { karyawan dan hotel. } \\
\text { 2. Menambahkan spot } \\
\text { foto dengan interior } \\
\text { yang menarik akan } \\
\text { membuat tamu } \\
\text { nyaman dan ingin } \\
\text { berkunjung kembali } \\
\text { ke hotel tersebut.. }\end{array}$ & $\begin{array}{l}\text { STRATEGI WO } \\
\text { 1. Menyediakan koran } \\
\text { atau media hiburan } \\
\text { pada saat tamu } \\
\text { menunggu proses } \\
\text { check-in dan check- } \\
\text { out agar terkesan dan } \\
\text { membuat tamu tidak } \\
\text { merasa bosan. } \\
\text { 2. Renovasi dan } \\
\text { penambahan lukisan } \\
\text { kaligrafi, melakukan } \\
\text { perubahan interior } \\
\text { dengan penambahan } \\
\text { wallpaper dan warna } \\
\text { bagunan dengan } \\
\text { menganti warna hijau } \\
\text { karna mengambarkan } \\
\text { lebih cerah dan adem } \\
\text { sehingga } \\
\text { memberikan } \\
\text { kenyamanan bagi } \\
\text { tamu. }\end{array}$ \\
\hline $\begin{array}{l}\text { THREATS (T) } \\
\text { 1. Akan bersaing } \\
\text { dengan hotel lain } \\
\text { yang } \\
\begin{array}{l}\text { memberikan lebih } \\
\text { service }\end{array}\end{array}$ & $\begin{array}{l}\text { STRATEGI ST } \\
\text { 1. Mempertahankan } \\
\text { pelanggan setia } \\
\text { dengan memberikan } \\
\text { pelayanan yang } \\
\text { maksimal. }\end{array}$ & $\begin{array}{l}\text { STRATEGI WT } \\
\text { 1. Melakukan } \\
\text { maintenance pada } \\
\text { sistim kerja komputer } \\
\text { yang digunakan } \\
\text { secara berkala agar }\end{array}$ \\
\hline
\end{tabular}




\begin{tabular}{|c|c|c|}
\hline $\begin{array}{l}\text { excellent kepada } \\
\text { tamu. } \\
\text { 2. Dengan adanya } \\
\text { perkembangan } \\
\text { zaman dan teknologi } \\
\text { maka desain interior } \\
\text { hotel rangkayo basa } \\
\text { akan kalah jauh dari } \\
\text { pesaing lainnya yang } \\
\text { lebih menarik. }\end{array}$ & $\begin{array}{l}\text { 2. Memberikan service } \\
\text { dengan ciri khas pada } \\
\text { seragam pakaian agar } \\
\text { terkesan pada } \\
\text { pandangan pertama. }\end{array}$ & $\begin{array}{l}\text { pada saat check-in } \\
\text { tamu tidak menunggu } \\
\text { terlalu lama. } \\
\text { 2. Menggunakan } \\
\text { kualitas pelayanan } \\
\text { dan memberikan } \\
\text { pelatihan tentang } \\
\text { pelayanan yang tepat } \\
\text { untuk meminimalisir } \\
\text { terjadinya komplain } \\
\text { pada tamu. } \\
\text { Meningkatkan dan } \\
\text { pemeliharaan desain } \\
\text { interior secara } \\
\text { berkala untuk } \\
\text { menghindari } \\
\text { kerusakan. }\end{array}$ \\
\hline
\end{tabular}

\section{Pembahasan}

\section{Berdasarkan Atribut}

Dalam meningkatkan daya tarik hotel hingga dibutuhkan sesuatu strategi buat menarik atensi calon konsumen, terdapat beberapa strategi yang bisa dicoba oleh hotel ialah terpaut dengan strategi positioning bersumber pada atribut yang meliputi lambang serta keberadaan/ posisi hotel. Mengemas identitas merek lewat lambang sama perihal nya menyelaraskan lagu serta irama. Lambang tersusun dari nama industri yang ditulis dalam wujud berbeda, dimana secara keseluruhan lambang berhubungan dengan kata, nama industri. Jadi Rangkayo Basa Hotel Padang kurang menggambarkan tampilan fisik bukti diri hotel syariah. Sepatutnya lambang wajib menarik serta kreatif sehingga gampang diingat oleh warga. Sehingga strategi SO yang bisa dicoba oleh hotel merupakan dengan mengombinasikan warna yang lebih mencolok pada tulisan huruf RB supaya lebih gampang dikenali tamu.

Memiliki lambang yang bagus merupakan suatu kekuatan yang dimiliki hotel, namun dengan perkembangan zaman yang semakin maju banyak nya pesaing yang memiliki lambang yang lebih menarik maka menimbulkan suatu ancaman bagi hotel sehingga strategi ST dengan menambahkan ukiran pada huruf agar pesaing tidak dapat menirunya. Beberapa tamu tidak mengetahui Rangkayo Basa merupakan hotel syariah dikarena lambang kurang menonjolnya bentuk syariah, Lambang tidak dapat terlihat jelas apabila dicetak pada banner, salah satu bagian dari atribut yaitu keberadaan/lokasi hotel berada pada zona merah tsunami sehingga strategi WO adalah menambahkan lambang khutbah masjid yang bercorak batik simpel dan elegan agar menggambarkan bahwa hotel Rangkayo Basa merupakan hotel syariah yang berlokasi diranah minangkabau Kota Padang, Dengan menganti warna lambang karena warna elemen visual untuk menarik perhatian, membangun citra sebagai hotel syariah dengan memilih warna hijau dan putih sebagai simbol ciri khas muslim, dimana warna putih melambangkan kesucian sedangkan warna hijau melambangkan kesejukan sehingga dapat dipadu padamkan dengan banyak warna ketika dicetak pada banner, berada pada zona merah tsunami maka strategi WO adalah rutin memberikan pelatihan sigap hadapi bencana tsunami pada karyawan hotel. Dalam mendukung kenyamanan tamu maka hotel harus memiliki strategi WT untuk menimalisir kesalah pahaman tamu terhadap status hotel sehingga memberikan tambahan pada nama lambang rangkayo basa muslim friendly, Memberikan pelatihan kepada karyawan sebagai pemandu, membuat 
keterangan agar bisa dipahami dan dipelajari dalam mengatasi kepanikan bencana agar tamu tidak merasa khawatir.

\section{Berdasarkan produk}

Dalam meningkatkan kualitas pelayanan hotel maka Rangkayo Basa harus mempertimbangkan unsur-unsur produk yang ada pada hotel, produk yang dimaksud adalah jaringan wifi, menu, Ac dan area parkir. Memiliki setifikat halal MUI, kebersihan Rangkayo Basa sudah sangat baik, memiliki musholla yang kamar di besar dan unik karena ada beduk besar disamping musholla merupakan suatu kekuatan yang dimiliki hotel. Dengan begitu hotel akan berpeluang mendapatkan kesan yang baik oleh tamu dan berkemungkinan terjadinya repeat booking dikemudian harinya. Sehingga strategi SO yang dapat dilakukan hotel adalah meningkatkan kualitas produk seperti tersedianya beragam channel $t v$, memproduksi produk dari supplayer yang memiliki sertifikat halal MUI, merupakan cara untuk memberikan kepuasan tamu sehingga dapat menimbulkan loyalitas bagi tamu dan berpotensi terjadinya repeat booking. Hal ini juga diperkuat dengan teori Menurut [8] "Kepuasan adalah proses kumulatif mewakili penilaian secara keseluruhan berdasarkan pada keseluruhan transaksi membeli dan mengkonsumsi produk pada suatu waktu". Memiliki setifikat halal MUI, kebersihan Rangkayo Basa sudah sangat baik, memiliki musholla yang kamar di besar dan unik karena ada beduk besar disamping musholla merupakan suatu kekuatan yang dimiliki hotel, namun kuatnya suatu kekuatan dapat goyah apabila kompetitor lain menawarkan produk yang lebih baik dari Rangkayo Basa maka menimbulkan suatu ancaman bagi hotel sehingga strategi ST yang dapat dilakukan hotel adalah mempertankan dan meningkatkan kualitas produk salah satunya menawarkan dan memberikan pilihan channel tv yang lebih menarik disaat jaringan internet bermasalah akan membuat tamu nyaman dan loyal terhadap hotel, memberikan pelatihan dan reward kepada karyawan tentang prosedur room attendant yang baik dan benar sehingga setiap karyawan memiliki tanggung jawab dan bekerja lebih giat apabila memberikan kesenangan untuk karyawan maka akan terciptanya lingkungan yang sehat, bekerja dengan cepat dan bersih sesuai harapan. Memiliki jaringan wifi yang lambat, tidak memiliki menu yang ciri khas, Ac yang kurang dingin, Area parkir yang sempit hal tersebut dapat dilakukan dengan strategi WO dalam mendukung kenyamanan tamu maka hotel harus menyediakan dan memenuhi kebutuhan tamu sehingga strategi yang dapat dilakukan hotel adalah melakukan selalu mengadakan pengecekan berkala pada router wifi agar jaringan dapat stabil setiap saat jam-jam tidur (3-4 pagi) sehingga tamu tidak terganggu dengan kejadian tersebut, pihak hotel menambahkan beberapa menu khas arab pada setiap hari jumat yang merupakan hari yang sangat mulia dalam agama islam. Dalam mendukung kenyamanan tamu maka hotel harus memiliki strategi WT yang dapat dilakukan hotel untuk selalu mengadakan pengecekan berkala pada router wifi agar jaringan dapat stabil setiap saat, melakukan maintenance Ac secara berkala guna mengantisipasi kerusakan barang secara tiba-tiba, memiliki area parkir yang sempit maka untuk meminimalisir keadaan dengan membeli lahan kosong yang ada disamping hotel guna ketika kamar dalam keadaan full accoupancy akan memudahkan tamu dalam mencari tempat parkir sehingga menimbulkan kenyamanan dan keamanan untuk kendaraan tamu.

\section{Berdasarkan Harga}

Dalam meningkatkan daya tarik hotel maka diperlukan suatu strategi dalam memasarkan barang dan jasa, setiap perusahaan harus dapat menetapkan harga yang tepat untuk menarik perhatian calon konsumen. ada beberapa strategi yang dapat dilakukan oleh hotel, seperti strategi promo atau potong harga untuk tamu langganan, mempunyai paket meeting room yang terjangkau, memiliki harga kamar yang murah merupakan kekuatan yang dimiliki oleh hotel Rangkayo Basa untuk menarik perhatian tamu. Program potong harga ini merupakan suatu keunikan bagi hotel, dimana dapat menjadi nilai tambah hotel dimata konsumen. Dengan adanya program potong harga ini hotel dan konsumen sudah terikat dalam suatu hubungan yang saling menguntungkan. 
Apabila hubungan ini dapat terjalin dengan baik maka akan munculnya loyalitas pada tamu. Maka strategi SO ini dapat dilakukan dengan memberikan diskon khusus pada hari besar islam, pihak hotel harus giat melakukan promosi paket meeting room dan kamar dengan menonjolkan yang akan dipasarkan. Hubungan antara tamu dan hotel dapat terjalin lama apabila program potong harga memberikan tawaran yang bermanfaat bagi para tamu, namun ancaman yang akan terjadi apabila tawaran yang diberikan tidak menarik dan kurang bermanfaat maka hubungan tidak dapat berjalan lama. Oleh sebab itu yang dapat dilakukan oleh hotel adalah menciptakan suatu keunikan pada promo agar pesaing tidak dapat menirunya, selalu memberikan informasi mengenai promo yang akan ditawarkan kepada tamu. Banyaknya tamu yang tertarik untuk melakukan pertemuan di Hotel Rangkayo Basa karena memiliki harga yang terjangkau sesuai dengan kualitas maka dari itu memiliki peluang bagi tamu bisnis sehingga strategi WO yang dapat dilakukan hotel adalah dengan membuat program membership untuk menarik tamu-tamu bisnis. Tidak menutup kemungkinan ancaman yang terjadi adalah hotel-hotel lain akan membuat tawaran promo yang tidak terduga yang akan menarik perhatian para anggota hotel. Sehingga strategi WT yang dapat dilakukan hotel adalah para marketing giat dalam menciptakan promo yang menarik agar tamu bisnis merasa puas dan tidak beralih kepada pesaing, dengan program membership yang menarik maka tamu bisnis dapat bertahan lama dan tidak melirik kepada pesaing lainnya.

\section{Berdasarkan Pesaing}

Semakin berkembangnya industri perhotelan maka para pesaing hotel bintang semakin banyak melakukan strategi-strategi dalam meningkatkan daya saing hotel. Salah satu indikator positioning berdasarkan pesaing meliputi perbandingan pelayanan dan desain interior. Rangkayo basa merupakan hotel syariah yang memiliki standart operasional prosedure check-in dan checkout sesuai syariat islam, memiliki pelayanan karyawan yang ramah, memiliki desain interior musholla yang unik dan memiliki perpaduan warna lampu yang tidak merusak pandangan mata merupakan salah satu kekuatan bagi hotel. Maka strategi SO yang dilakukan hotel dengan menjaga dan meningkatkan standar operasional prosedure service excellence dengan baik akan membuat tamu merasa nyaman saat berada dihotel, menambahkan spot foto dengan interior yang menarik akan menambah kesenangan tamu dikarenakan seiring perkembangan teknologi banyaknya masyarakat menggunakan media sosial sehingga hotel bukan hanya dijadikan tempat istirahat tetapi juga tempat rekreasi seperti dijadikan tempat untuk spot berfoto. Dengan banyaknya kompetitor maka semakin berlomba-lomba untuk menciptakan suatu daya tarik untuk menarik perhatian tamu menginap, maka akan menjadi ancaman bagi hotel Rangkayo Basa

sehingga strategi ST yang dapat dilakukan hotel adalah mempertahankan pelanggan setia dengan memberikan pelayanan yang maksimal, memberikan service dengan ciri khas pada seragam pakaian agar terkesan pada pandangan pertama. Selain kekuatan Rangkayo Basa memiliki kelemahan terhadap pelayanan dan desain interior seperti proses check-in dan check-out lama, karyawan kurang tanggung jawab dan emphaty dalam memberikan pelayanan, kurang siggap dalam menghadapi komplain tamu, desain interior hotel kurang menonjolkan syariah, desain pada warna interior kurang mencolok. Maka startegi WO yang dapat dilakukan hotel adalah menyediakan koran atau media hiburan pada saat tamu menunggu proses check-in dan check-out agar terkesan dan membuat tamu tidak merasa bosan, renovasi dan penambahan lukisan kaligrafi, melakukan perubahan interior dengan penambahan wallpaper dan warna bagunan dengan menganti warna hijau karna mengambarkan lebih cerah dan adem sehingga memberikan kenyamanan bagi tamu. Dengan adanya kelemahan banyaknya tamu yang merasa kurang puas sehingga akan mempengaruhi minset tamu dan akan adanya kompetitor yang menawarkan pelayanan yang lebih baik dari hotel Rangkayo Basa. Sehingga strategi WT yang dapat dilakukan hotel adalah melakukan maintenance pada sistem kerja komputer yang digunakan secara berkala agar pada saat check-in tamu tidak menunggu terlalu lama, menggunakan kualitas pelayanan dan memberikan pelatihan tentang pelayanan yang tepat untuk 
meminimalisir terjadinya komplain pada tamu, meningkatkan dan pemeliharaan desain interior secara berkala untuk menghindari kerusakan.

\section{KESIMPULAN}

1. Hotel mempunyai positioning berdasarkan atribut yang meliputi lambang dan keberadaan/lokasi yang kurang bagus dan kurang melekat dibenak pelanggan seperti keberadaan lokasi yang strategis namun berada pada zona merah tsunami membuat tamu merasa khawatir, memiliki Lambang yang kurang menonjolkan syariah, lambang tidak dapat terlihat jelas apabila dicetak pada banner merupakan suatu catatatn bagi pihak hotel untuk dapat memperbaiki berdasarkan pendapat dari tamu agar lebih baik kedepannya.

2. Hotel mempunyai berbagai macam produk inti seperti kamar, restoran, meeting room. Semua produk yang ditawarkan hotel dalam kondisi yang bersih, bersetifikat halal MUI namun untuk mendukung kualitas produk inti hotel harus memperhatikan produk seperti jaringan wifi, ciri khas menu, kondisi Ac, dan lahan parkir untuk saat ini masih belum memadai.

3. Dalam penetapan harga Rangkayo Basa Hotel mempertimbangkan patokan harga pada tiap-tiap produk yang ditawarkan, penetapan harga berdasarkan pada lokasi, pesaing sekitar, fasilitas hotel dan pelayanan hotel. Positioning terhadap harga dapat menarik perhatian tamu dan melekat dibenak tamu dikarenakan memiliki harga yang terjangkau dan adanya promo dengan memberikan pada harihari tertentu seperti hari besar islam, aniversary hotel, kemerdekaan RI, idul fitri, tahun baru dan hari besar lainnya, menawarkan membership bagi tamu bisnis.

4. Positioning berdasarkan pesaing meliputi perbandingan pelayanan dan desain interior masih belum memuaskan dan kurang melekat dibenak tamu dikarenakan pada saat proses check-in dan check-out tamu masih menunggu terlalu lama, karyawan kurang tanggung jawab dan emphaty dalam memberikan pelayanan, karyawan kurang sigap dalam menghadapi komplain tamu, kemudian perbandingan interior berdasarkan desain interior hotel yang mana masih kurang menonjolkan syariah, desain pada warna interior kurang mencolok. 


\section{DAFTAR PUSTAKA}

[1] Pemerintah Indonesia. 2009. Undang-undang Dasar Nomor 10 Tahun 2009 tentang Kepariwisataan Pemerintah Pusat. Jakarta.

[2] Chair, ira Meirina dan Pramudia, Heru. 2017. Hotel Room Division Management.Jakarta:Prenadamedia Group.

[3] Kotler, P., \& Keller, K.L (2016). Marketing Management, Global Edition 15e. United States of America:Person Education,Inc.

[4] Herlambang, Susatyo. 2014. Basic Marketing (Dasar-dasar Marketing) Cara Mudah Memahami Ilmu Pemasaran. Yogyakarta : Gosyeng Publishing.

[5] Basmallah,2011. Hotel berbasis syariah. Jakarta.

[6] Rangkuti, F (2016). Teknik membedah kasus bisnis Analisis SWOT.

[7] Sugiyono.Metode Penelitian Kuantitatif Kualitatif Dan R\&D. Bandung : Alfabet. 2019

[8] Susepti, Amalia. Pengaruh Kualitas Pelayanan Terhadap Kepuasan dan Loyalitas Tamu Hotel.Jurnal Administrasi Bisnis Vol.50 No 5, hal 29. 2017 